\title{
Exploring the critical moments when the Baptist denomination divided: Does revisiting these moments give hope to reconciliation between the 'Union' and 'Convention'?
}

\author{
Authors: \\ Luvuyo Ntombana ${ }^{1}$ \\ Adam Perry ${ }^{1}$ \\ Affiliations: \\ ${ }^{1}$ Fort Hare Institute of Social \\ and Economic Research \\ (FHISER), University of Fort \\ Hare, South Africa

\section{Correspondence to:} \\ Luvuyo Ntombana \\ Email: \\ Intombana@ufh.ac.za

\section{Postal address:} \\ Fort Hare Institute of Social \\ and Economic Research, 4 \\ Hill Street, East London 5200, \\ South Africa \\ Dates: \\ Received: 07 Feb. 2011 \\ Accepted: 12 Dec. 2011 \\ Published: 05 Mar. 2012 \\ How to cite this article: \\ Ntombana, L. \& Perry, \\ A., 2012, 'Exploring the \\ critical moments when \\ the Baptist denomination \\ divided: Does revisiting \\ these moments give hope to \\ reconciliation between the \\ "Union" and "Convention"?', \\ HTS Teologiese Studies/ \\ Theological Studies 68(1), \\ \#Art. 1029, 8 pages. http:// \\ dx.doi.org/10.4102/hts. \\ v68i1.1029
}

(C) 2012. The Authors. Licensee: AOSIS OpenJournals. This work is licensed under the Creative Commons Attribution License.
This article evaluated interpretations between members of the Baptist Union of South Africa (BUSA) and the Baptist Convention of South Africa (BCSA), revisiting a particular moment, the merger talks of 1980s, at the time when the Baptist Church further entrenched these divisions. The Baptist Church has a crippling historical relationship to the present, particularly as members of the faith interpret their sides of the story as being the 'right' ones. This article grew out of the ethnographic work undertaken by the primary author, Luvuyo Ntombana (2007), and his involvement with the Baptist Church. It is felt that in order to create a sacred Church, congregations ought to move away from arguing about past events toward a more positive rethinking of what lessons can be learned from the past. Therefore, this article argued that by revisiting critical moments for the Church, such as the period of reconciliation between denominations within South Africa, conversations can be reinvigorated to help reconcile and unite current factions which currently harbour animosity and weigh down the faith through unnecessary infighting.

\section{Introduction}

In every country one cannot divorce the Church from the context in which it exists. This is so because Church members are an integral part of the broader social structure, which is also informed by the socio-economic and political conditions. Such conditions have a large impact on the mission and continued existence of the Church. South Africa is no exception to this reality of the link between Church and society. Baptist denominations, which are part of the wider South African community, were greatly affected by colonialism and apartheid's dramatic and devastating policies. The relationship between the Baptist Union of South Africa (BUSA) ${ }^{1}$ and Baptist Convention South Africa (BCSA) is a reflection of the colonial past which was guided by the policies of apartheid and racial discrimination (Hale 2006:754). Since the formation of these organisations, the BUSA was considered the 'mother body' and, as a result, made decisions for the BCSA often with little or no consultation (Rae 2004:1). The situation of White Churches assuming the 'mother body' position was not only experienced amongst Baptist denominations but was a generic occurrence amongst all Christian Churches in which there were Black and White congregations (Rae 2004:1).

During the mid-1980s, however, South African Churches wrestled with their own identity in relation to apartheid, liberation and reconciliation. At this time, the South African Council of Churches, and its affiliates, met at various meetings to engage with one another. The main intention was an attempt to develop an alternative biblical and theological response (against apartheid) in order to make a real difference to the future of South African citizens. These various meetings and engagements resulted in the publication of various documents, such as the Belhar confession (1982), The Kairos document (Kairos Theologians 1987) and The Barkly West national awareness workshop (eds. Hoffmeister \& Gurney 1990). These documents were meant to give a clear direction for the Church to move away from racially segregated policies of apartheid and, further, to raise a Christian voice regarding the state of affairs at the time. The core messages embedded in the above documents were justice, equality, peace, reconciliation and freedom for the oppressed. It is in this context that members of the BUSA and BCSA initiated to merge the two bodies. Yet after a marathon of meetings between 1982 and 1987, the merger talks failed to achieve this intention. The subsequent result was that some members of the BCSA joined the BUSA, whilst others remained with the Convention. Subsequently, the Convention took an independent stand and ended its affiliation to the Union.

1.From this point on, reference is made to the Churches by their acronyms, BUSA and BCSA. In some cases, reference is made to the Churches simply as 'Union' or 'Convention', as these latter terms are known more commonly by congregants and remain recognisable terms today. 
Again from the early 1990s, during the democratisation process in South Africa, the BUSA and the BCSA joined the country and other Churches in attempts to form reconciliatory initiates and to provide peace to much divided South African Christian Society. The BUSA and BCSA responded to the call by the Truth and Reconciliation Commission (TRC) to confess and find ways to forgive and accept one another in order to build the rainbow nation. Consequently, from 1995, various reconciliation meetings were held between members of these organisations. Apart from other issues that were discussed in the reconciliation meetings, the major subject that seems to have characterised the meetings was the historical interpretation of the merger discussions which took place between 1982 and 1987. An analysis of the minutes of these reconciliation meetings and ethnographic engagement with Church culture at the grass roots level suggests that one of the major issues continues to be how members interpret historical events of the time (Ntombana 2007:117). Seeing that the issue of historical interpretation is important to both Baptist groups (and to these particular moments in time), it seems imperative to evaluate the historical events of the merger discussions. The main focus of this article is therefore how each organisation interprets the merger discussions which took place between 1982 and 1987.

The intention of this article is not to discuss the methodologies or historical philosophies of interpretation, but rather to revisit critical moments, or points of departure, which divided the BUSA and BCSA congregations. More to the point, we argue for the need of Baptist members to come together, at this particular moment in time. The Baptist Church needs to rethink its strategy and try to reconcile its divided past. Whilst the moments for potential reconciliation may have come and gone during the TRC process, it is not too late to make strides to bring congregations together in search of harmony. The moment should come; bad blood between the BUSA and BCSA members should end, with the understanding that the past can be healed if there exists strong faith to make it happen. Even though this article focuses on a narrow time period - when the Baptist Church could have merged more appropriately, but did not - an analysis of why reconciliation failed within the Church remains important to the contemporary discussion.

\section{Hypothesis}

If the history of the Convention and Union can be understood more critically as a reflection of the ills of apartheid, revisiting particular moments when the BUSA and BCSA have tried to come together, but failed, may help stimulate positive debate for how these groups can move forward, united, in the future.

\section{Historical background}

In brief, the Baptists first came to South Africa from Europe with the German and English settlers in the early 1800s and the first Baptist church was established at Salem near
Grahamstown in 1820. The Baptist Union of South Africa was formed in 1877 and adopted a Missions Policy to reach out to the indigenous inhabitants with the Gospel (Rae 2004:1). The Bantu Baptist Association (which later became the BCSA in 1965) was formed as a Mission Church outreach by the BUSA in 1927. The BCSA consisted of indigenous Black African churches as a distinctive and yet dependent entity. White members belonged to the Baptist Union of South Africa; conversely, the Baptist Convention of South Africa was for Black believers (Rae 2004:1). The BUSA was considered the 'mother body', with the BCSA depending on the BUSA for recourses. This resulted in Black members being treated as second-class citizens. The structure of the two bodies reflected colonial Africa as the racial divisions imposed by apartheid policies in South Africa had a widereaching impact on how cultural values within the Church formed (Kretzschmar 1996:36; Rae 2004:1). Whilst some in the Convention may have desired to detach from the Union, because a hegemonic relationship existed in the fact that the organisation required funds to operate, members ultimately had to remain affiliated with the 'mother-body', the Union, to survive. The apartheid system became a force that divided the two dominant Baptist Churches to such an extent that enmity was created between them (Kretzschmar 1996:36). As with other denominations, such as the Presbyterians, Dutch Reformed and Faith Mission Churches, the apartheid system effectively created separate Black and White Churches.

Critics of this allegedly paternalistic system attributed its existence to the unwillingness of many White Baptists to integrate their churches and give African Christians autonomy to the same degree that they themselves enjoyed (Hale 2006:772). The education of the Convention pastors was kept at a minimum and subjected to the standards imposed by the White Baptist Union (Mhlophe 1990:55). In looking at the BUSA and its response to apartheid and its policies, Hale (2006) suggests that one needs to acknowledge that from the formation of the BUSA to date, the voice of the BUSA within politics has not been the same, moving through three distinct phases. He suggests that prior to the National Party's rise to power in 1948, the BUSA openly took a stand against racial policies, discrimination and oppression of Black people (Hale 2006:758). Hale (2006:759) asserts that the second phase of the BUSA's political stance occurred after apartheid had been instated, for this was the time when the BUSA was silent on these matters and was reluctant to speak against the policies and the treatment of Black people in townships. The last phase occurred during the early 1980s, when a change of heart was observed amongst the BUSA members, resulting in the organisation once again taking a stand against the apartheid leaders and openly criticising the apartheid government. This final shift was followed by an open letter from the BUSA to President Botha calling for the termination of apartheid and the execution of other major reforms (Hale 2006:765-766). One needs to acknowledge that it was not only the BUSA which had different approaches to political involvement; this was the same situation with other denominations. There are perhaps various reasons for this, such as the state of the country at the time, the political 
situation on the ground, pressure from the international community and the Church leadership at the different times. The discussions of merging the BUSA and BCSA that took place in the 1980s therefore has to be understood in light of a political awakening in South Africa, which stirred the Church not to be silent but to take a stand against apartheid (see the section below entitled 'The merger discussions of 1982-1987').

\section{Confessions and reconciliation initiatives}

With the advent of democracy in 1994, South Africa embarked on trying to heal the wounds of a much divided past; the process was facilitated through the internationally well-recognised Truth and Reconciliation Commissions. South African government, under the leadership of Dr Nelson Mandela, recognised that reconciliation is a religious and a spiritual concept and none other than religious and spiritual leaders could lead its process. As a result, religious leaders were tasked to officiate the TRC, with Archbishop Emeritus Desmond Tutu as Chairperson. The Christian community understood the reconciliation process as 'a calling', as biblical scriptures proselytised the message that to reconcile ought to be a 'calling' for all (2 Cor 5:16-21; Eph 2:11-22). Some denominations, such as the Presbyterians, Dutch Reformed and Baptists, joined in the common goal to unite the country through reconciliation and unity and move away from divided denominations. The result of this process meant that denominations often gathered together at this time, in efforts to unite for a more common good.

The BUSA and BCSA followed suit and publicly confessed and forgave each other; the confessions ${ }^{2}$ were led by the general secretaries: Rev. T. Rae, from the BUSA and Rev. D. Hoffmeister from the BCSA. During the confessions, both parties made it clear that the confessions were made in consultation with their organisations and they were speaking on behalf of their constituencies. The confessions were further understood to be the foundations of the reconciliation process and an encouragement to their members to facilitate local reconciliation processes of their own. The Baptist World Alliance (BWA), which is the international Baptist body through which the BUSA and BCSA are affiliated openly, encouraged the two organisations and offered its assistance whenever needed (Ntombana 2007:58).

The reconciliation meetings were followed by different national, and in some cases regional, meetings and local church meetings were encouraged as well. In the process of the reconciliation meetings, it became clear that both organisations had different understandings concerning the events that had led up to the present situation. As mentioned before, the major disagreements were on the nature of the process that occurred between 1982 and 1987, as well as the merger discussions. The national, regional and local 2.Confession submission to the TRC by Rev. D. Hoffmeister in 1997 (http://web.uct ac.za/depts/ricsa/commiss/trc/bcsa_sub.htm). Confession submission by Rev. T. Rae in Cape Town in 1997 (http://web.uct.ac.za/depts/ricsa/commiss/trc/bap_sub. htm). reconciliation meetings were dominated by how each body interpreted the historical events pertaining to the merger discussions. It appeared that each group wanted to justify their actions and accuse the others of being on the wrong side. It is true that some of the proceedings were conducted in the spirit of prayer and forgiveness, but most of the time such good endeavours were overshadowed by the justification of one another's actions by how they each interpreted and justified their actions in relation to the merger talks of 19821987 (Ntombana 2007:39).

Other weaknesses of the reconciliation meetings were that the majority of attendants were Black people, with the majority of White members showing little interest in the meetings. If one talks about true reconciliation, how do we then reconcile only Black members? Ntombana (2007:54) has questions that 'if one talks about true reconciliation, how do we reconcile when only Black members are present'. Another challenge was that most of the reconciliation meetings took place in Johannesburg and were attended by few members from outside this region, as most could not afford to travel there. This means that there was little involvement of people at a grass roots level (Ntombana 2007:57). Furthermore, it was encouraged that each region should have reconciliation meetings of their own to facilitate forgiveness and reconciliation, but no monitoring measures were put in place to make sure that such meetings occurred. In addition, contrary to the reconciliation meetings of Dutch Reformists and Presbyterians, who clearly defined that they wanted unity of the divided structures, the Convention and the Union did not come out and identify the unity of their churches as their ultimate goal. There were only some discussions and wishes about the Baptist organs becoming one when reconciliation was successful. The move on their part was more one of saying: 'let us reconcile and see if it would lead to union of the two organs.' Even when the idea of only one 'Baptist voice' was mentioned, it was never unpacked as to how this was going to be achieved. All of the above observed weaknesses mentioned, in addition to the major discussions that characterised the reconciliation meetings, as well as the observations on the local church level, suggest that the major disagreement between the two organisations centred on issues of historical interpretation, as argued in this article.

\section{The merger discussions of 1982-1987}

The political situation worsened after the Soweto Riots of 16 June 1976. This was a major political explosion led by South African students against apartheid policies, in particular, the introduction of Afrikaans as a medium of instruction in local schools (Ndlovu 1998:1). On this day, an estimated 20000 students took to the streets in a peaceful demonstration to express their dissatisfaction at apartheid policies and the apartheid regime responded with unbridled violence. As a result, more than 500 students were killed and thousands were injured. Yet, instead of giving up, Black people in the townships all over South Africa became progressively more resistant to minority White domination and it seemed as if they were increasingly willing to die rather than accept 
apartheid dominion (Brooks \& Brickhill 1980:25). Indeed, after this event many more South African people began wrestling against an apartheid system the government was not willing to change. The struggle was intensifying, as more and more people were being killed, maimed and imprisoned. In the 1980s, a number of theologians and churches became concerned and expressed the need to reflect on this situation. The purpose was to determine what response should be forthcoming from the Church as a whole, as well as Christians in South Africa, which would be most appropriate and based on the Word of God? As mentioned above, this stand resulted in various theological debates and the publication of documents, such as the Belhar confession (1982), The Kairos document (Kairos Theologians 1987) and The Barkly West national awareness workshop (eds. Hoffmeister \& Gurney 1990), which openly opposed the apartheid system from a biblical perspective; their argument was that apartheid is heresy and therefore it has to be opposed by all those who are true Christians (Kairos Theologians 1987:5).

It is in the light of this historical context that the BUSA and BCSA came up with a suggestion to open discussions on how to merge. On 14 September 1985, the Liaison Council was established, comprising seven members from each organisation (Makhanya 1990:39). Its mandate was to find a meaningful solution to improve the relationship between the Union and Convention, which, at that time, was well divided between White and Black members, respectively. The Liaison Council recommended that the BUSA and the BCSA seek ways and means by which their autonomous structures could be modified, so as to make it possible for all Baptist Churches to participate meaningfully, and with equity, in the denomination (Makhanya 1990:39). It was further suggested that the merger between the two bodies was a possible solution to this problem (Rae 2004). These discussions continued until 1987, by which time it became clear that both organisations could not reach consensus on the issue of a merger. Ten years later, in his paper to the BWA, Rev. T. Rae (2004) had this to say about the merger discussions:

During this period further meetings were held between BCSA and BUSA in which both parties sought to justify their positions and little progress toward understanding was made. In retrospect there was continual misunderstanding of each other, not really listening to each other and there was unwillingness for anyone to admit blame or fault. These meetings resulted in a build-up of bitterness, frustration, lack of understanding and lack of a repentant spirit.

Instead of merging with the BUSA, the BCSA withdrew its status of affiliation and opted to become an independent body. Some BCSA local churches and some individuals resigned from the BCSA, opting to join the BUSA. The Black churches that joined the BUSA can be classified into two groups. There were those who joined because they had reason to; these churches comprised members who were aware of what was going on and decided to join the BUSA voluntarily. There were also those who were not aware of the politics of BUSA and BCSA, but because the pastors were joining the BUSA, they joined automatically. In these cases, the members were not consulted about the move (Ntombana 2007:38). This became a very painful experience, especially at the local church level where the conflict was within Black BCSA churches (Ntombana 2007:43). This caused untold bitterness, hurt and anger between Baptists in South Africa. Both groups were convinced that they were taking the right decision at the time. The BCSA members who refused to accept the merger argued that they were taking a stand in line with the Black Church in South Africa at the time and accused those who joined the BUSA of betraying and selling out their brothers to White people.

The BCSA leaders were part of the group of churches that adopted The Kairos document (1987), whilst the BUSA distanced themselves from the meetings that resulted in its formulations. The main message of this document was that there can be no true reconciliation and peace without justice (Kairos Theologians 1987:3). Any form of peace or reconciliation that allows the sins of injustice and oppression to continue is a false peace and counterfeit reconciliation; this kind of reconciliation has nothing to do with the Christian faith (eds. Nurnberger \& Tooke 1998:11). This argument suggests that if the BUSA was serious about unity, then it would have joined other leaders, such as Beyers Naude, in fighting against the apartheid system together with the Black Church. What was important to the BCSA members at the time was liberation from State oppression. According to the words of Rev. Simon Lukwe, 'How could we talk about merging with the Union while the very same Union members were the ones killing innocent people in black townships?' (cited in Ntombana 2007:70).

According to the minutes of the March 1995 national meeting between the BUSA and BCSA held in Johannesburg, another reason was that the BCSA members felt that, based on their experiences of treatment by White moderators and BUSA members, the merger idea was just another way of trying to control them. Some BCSA members expressed a view that the BUSA was arrogant and unrealistic about merging with the BCSA, arguing that from the statements presented by the then president and the general secretary of the BUSA at the Convention Assembly on 16 June 1986 in Amanzimtoti, the BUSA was prepared to talk but not seriously work towards a genuine merger (Makhanya 1990:39). Furthermore, it was argued that the BUSA understood merger to mean 'grafting into its present existing strictures all those who come to beg for membership' (Makhanya 1990:39). The majority of the BCSA members expressed a view that the BUSA did not have intentions to be equal with the BCSA members but receive the BCSA as subordinates and therefore, in essence, this was not different from the relationship that existed at the time (Makhanya 1990:39). Makhanya (1990:40) goes on to assert that the BCSA members wanted to be equal with the BUSA members and that is something the BUSA was not willing to give; hence, the BCSA members opted to be independent of the BUSA and rejected the merger.

From the March 1999 minutes of the Durban meeting, Rev. G. Ngamlana, one of the pastors who decided to join the BUSA, 
declared that the decision of the BCSA to refuse to accept the merger was a premature decision. He believed that the BUSA was sincere when they approached the BCSA in 1982 asking for forgiveness and suggesting a merger. According to Black BUSA members, the BCSA members were politically motivated in their decision against the merger (Ntombana 2007:38). In this view, the Church was not supposed to take the side of worldly politics but preach the gospel of reconciliation with one another. Therefore, the merger suggestion was sincere and undertaken with a good purpose, which was to unite the divided Baptist Church.

One of the areas of disagreement was whether BUSA opposed the apartheid system or not. The BUSA argued that even if they had been silent towards apartheid for a long time, later there had been a change of heart and they confronted apartheid and its policies. The letter written in 1987 by the BUSA executive to the South African government opposing the apartheid system stated that the BUSA was totally against the torturing and killing of Black people in townships (eds. Nurnberger \& Tooke 1988:28). The argument of the BUSA in quoting such a letter and other documents was that even though they had supported apartheid for a long time, they changed and started confronting the evil of apartheid after 1985, wanting to take a different stand from that of their fathers. The March 1999 minutes indicate that Rev. Rae shared the same sentiments in his question as to why the BCSA was judging and punishing the BUSA, based on what their forefathers had done. Here, he stated that 'the BUSA of 1970 is no longer the BUSA of today'. This view was further supported by Tutu (1997:8), when he maintained that the White people of South Africa are, in their own way, also victims of the apartheid system.

On the other hand, the BCSA members felt that the BUSA, as with other White churches, did not do enough to oppose the apartheid system (Ntombana 2007:38). The argument of the BCSA was strongly supported by Prozesky (1990:220), who maintained that the agents of oppression were, in many cases, active Christians themselves. He argued that all White South Africans were guilty of the sin of apartheid, except for a few individuals such as Rev. T. Hudson, a Methodist minister who identified himself with Black people, Dr L. Kretzschmar, the only White member of the BCSA, and some few others who identified themselves with the oppressed. Prozesky (1990:220) went on to argue that, if White Christians were against violence, then they could have at least used non-violent actions to oppose the apartheid regime.

Dr R. Richards (1996:45), a Coloured pastor who studied theology in 1985 at the Baptist Theological College in Cape Town, held one of the few seminaries with both Black and White students at the time. He explained how he overheard White students talking about their mission to townships in the evening to join the police force in the torturing of Black people. In reaction, he asked, what the fellow brother would do if he found himself in the township during this mission? The White brother answered without any hesitation: 'I would have no option but to shoot you!' This surprised Dr Richards and other Black students, because they were being taught that, as Christians, they were not supposed to be involved in riots and politics in townships. It became clear to them that the teaching of 'no involvement' in politics was just a tool being used by White people to make sure that Black students would submit to White supremacy (Richards 1996:45).

We can go on and on examining the events of the past and how they are interpreted by different groups. The point here is to suggest that instead of coming up with a solution to merge, discussions created more enmity between Baptists, ending up with people accusing one another. It became clear in the reconciliation meetings that different historical interpretations of facts had led to a dead end; the harder they worked on debating the issues of the past, the more impossible it became to find a solution. What seems to have superseded the discussions during the reconciliation meetings was how each group perceived their past, especially the merger discussions that took place in the 1980s. Some BCSA members continue to refer to their Black brothers and sisters who left for the BUSA as traitors who sided with White people. Whilst the BUSA Black members refer to those who opted to be independent (BCSA) as those who broke away for political reasons. There continues to be a rift in the Baptist community, which runs deep to the hurt of this historic and divided past.

\section{The importance of rethinking key historical moments}

The interpretation of history by the Baptist groups has caused a sharp division, with the BCSA accusing the BUSA of telling lies and vice versa. Both Churches have personalised the conflict that arose out of the differing interpretations of the past. This sharp dispute is caused by the fact that, in reflecting on the past, there is a more often than not a mission to fulfil (Bermejo-Barrera 1993:14). In this case, each organisation has the mission of proving their side of the story to be the correct one.

Interpreting the past as it gives meaning to the present situation is quite normal. People studying history need to realise that the so-called facts of history are not always arrived at objectively, but rather through subjective lenses (Mccullagh 2000:49) This does not mean that facts do not exist; rather, it might simply mean that facts are both selected and interpreted differently (Braun 1994:172). Two people recording the same event may interpret facts differently or even select other facts to interpret the past (Shafer 1971:24). We have a clear biblical example of this in the Synoptic Gospels, where some facts on the events of Jesus' healing ministry are selected and interpreted differently. One such instance relates to the healing of demon possession found in Matthew 8:28-33, Mark 5:1-20 and Luke 8:26-32. According to Matthew, two men who were demon-possessed were healed, whilst Mark and Luke each record that only one demon-possessed man was healed. There are other 
differences as well as similarities in how these three stories are recorded. One of the similarities is that all texts mention the use of chains as measure to control the man or men. Furthermore, that when the evil spirit came out it went to the herd of swine (Mt 8:32; Mk 5:13; Lk 8:33). Even though the Synoptic writers phrased their stories differently, the Bible readers still appreciate the Synoptic agreement on the fact that the healings did in fact take place (Thomas 2005:8).

The subjective interpretation is a normal exercise; there is nothing wrong with having different stories. The objective knowledge of the past can only be obtained through the subjective experience of the interpreter (Stanford 1987:27). Dray (1980) phrases this aptly:

The historian or interpreter is not an observer of the past that lies beyond his own time. He cannot see it objectively as the chemist sees his test tubes and compounds. (p. 27)

In the writing and interpretation of history there are always bias accounts which emphasis the role of those aspects the historian wants to praise or blame for its success or failure, ignoring the equally significant contribution of others (Mccullagh 2000:52). Thus, the subjectivity in interpretation should not be seen as a dividing force, but rather as a necessary exercise that will help us to understand one another. Subjectivity is thereby not just about past events, but also involves the feelings and attitudes of the storyteller (Tunca 2009:11). If we want to move away from conflict to harmony, confronting feelings and attitudes is most likely unavoidable, as subjective interpretation is part and parcel of the human experience.

Historical studies and interpretation are said to be distinctively subjective (Mccullagh 2000:50; Rusen 2005). Therefore it is important to understand differences about the past in a more in-depth way, in order to ascertain where such differences originate from and how they continue to be interpreted and reinforced. Interpretations cannot be resolved, regardless of how much access we have to the evidence, without some sort of reflection on pivotal points in history (Martin 1993:38). These moments in time often need to be revisited in order to help frame current discourse and debate, with the aim that new insight can be brought to the forefront of the discussion.

In order for the BUSA and BCSA to come together and reflect on their shared history, it is hoped that those divides, which continue to be entrenched, can be thought anew and perhaps reconciled. Arguments stemming from individuals within the BUSA and BCSA are very much driven by sentiments of moral rightness, which goes beyond historical interpretation, reliving the past and continuing to divide people in the present moment. Main issues which divide these groups are whether the BCSA members were justified in opting to be independent from the BUSA, and whether the White Baptist members were vocal enough against the apartheid regime. Despite these strong sentiments, it is hoped that revisiting the moment when these views were divided may shed new light and help these groups move passed their bitterness.
In his analysis of the context of modernity, Bevir (1994:33) argues that there is no such thing as history but only 'histories'.

By embracing this perspective, instead of looking for one absolute history, the BCSA history and the BCSA history should both, in their own way, be acceptable. These are two different histories that come from different organisations that seek to bring light to their different experiences of the past. Bevir's suggestion seems to address the long and ongoing debate of subjectivism and objectivism in historical interpretation. If both organisations can embrace the existence of histories, then they will learn to appreciate each other's stories and understand the impact each history has had on the other. Beyond this, by showcasing that a particular few moments were the potent force separating these groups along bitter lines, it is hoped that such recognition may invigorate these groups to take stock of their current situation and move beyond the historical facts which seem to bind them.

\section{The major cause of the bitter divide}

There are some challenges that are created by the interpretation of past events. Braun (1994:174) notes that, 'the realization of historical interpretation may be contextualized, extra-textualized and detexualized, but in the end the factual reality of the past should not be compromised or denied'. In light of this statement, the following question could be posed: What is it that can be regarded as a factual reality of the past in the case of the BUSA and BCSA history? We propose that both organisations need to find a common history. This can help these groups understand what they have shared and what events have shaped their current situations; have shared and what; a history which, for all intents and purposes, has resulted in much bitterness amongst those within the Baptist denomination. The BUSA and the BCSA should, at least, agree on the fact that the apartheid system was cause for the difficulty these groups faced in merging, and for the very split within the Church, which was based purely on race.

\section{Is reconciliation possible?}

It is clear that the historical interpretation of the two bodies, BUSA and BCSA, hinders reconciliation because these groups vie for their own agendas. Perhaps, it is time to revisit what divides them and to concentrate on what brings them together. Their commitment to faith and Christian values could, at least, bind these groups together as they share common ground on this point. Much more to the point, both the BUSA and BCSA hold the same presuppositions concerning the Bible and this very fact should bring these groups together.

The following recommendations are based on the Christian values and principles which define the faith of both organisations. Williams (2004:129) recognises that apartheid was a 'structural sin', where individuals and groups were wrong to participate in systems opposed to the teaching of 
the Bible. As Christians following the Bible, this also means respecting other followers regardless of one's skin colour. If the BUSA and BCSA are to move forward, it is this same understanding that needs once again to reinforce the notion of the Bible in which all men, women and children are equal under God; these are his children. The Bible (Eph 4:10) teaches us that our struggle is not against flesh and blood, but against the principalities of darkness in Heavenly places. This scripture suggests that our enemy is not the BUSA or BCSA organisations, or even White or Black people, but the devil. In the process of any reconciliation, the two organisations carefully need to identify who their real enemy is.

The current Christian discourse should not be ruled by historical moments, such as the failures of the BUSA and BCSA to merge in the 1980s; rather, the spirit of reconciliation and forgiveness should drive current discussions. We have seen the importance of particular points in time and place, such as the events of the TRC proceedings, when the country was able to expose the brutalities of the past, but also when people of South Africa were able to heal and move forward (Ntombana 2007:57). In Christian terms, when we do things with Christ in our hearts, our eyes are opened and we see a need to reconcile with each other (Mitchell 1991:75).

In Gods' Way, reconciliation is not just a privilege of being in union with Christ, but a call to allow him to remove our human weakness and stubbornness towards our brothers and sisters. In describing human weakness, Sinclair (1996:159) puts it so succinctly: 'That man, as sinful and arrogant in his foolish pride, considers himself his own judge inevitably vindicating himself and pronouncing others guilty'. For Christians, reconciliation with God through Christ removes, or it is supposed to remove, the stubbornness and unwillingness to repent, as well as offering opportunity to reconcile with one's brothers and sisters for one's wrongs (Mt 5:23). The scripture in Matthew 5:23 challenges both parties to recognise that they each have a reason to repent and reconcile with each other. Realising that in any quarrel, fight or disagreement, when one adamantly claims to be 'right' and the other 'wrong', then the opportunity for reconciliation is lost and the above scripture commands both groups (claiming to be on the right) to go and ask for forgiveness. No one likes to admit that they have sinned against their brothers and sisters and, similarly, no one likes to admit when they are wrong. However, without this honest humility, as the teaching of Christ reveals, moving to a place where healing can be allowed to occur is difficult. Baptist denominations (considering themselves as people of the Book) are in a better place to understand these teachings. However, without a return to those pivotal points in history which have divided the BUSA and BCSA, and without a return to some of the teachings within the Bible, we doubt the two groups will be able to reconcile. One important lesson to learn is that we cannot reconcile the broken relationships without accepting and dealing with our own brokenness. Baptists, who preach the Gospel of reconciliation between humans and God, should look into their own relationships as they reach out to others.
The enmity of the BUSA and BCSA which currently exists can be put to an end and new friendships of reconciliation can take place. This has more potential to happen for the Baptist community if the values instilled in the Bible are embraced and if members from both the BUSA and the BCSA remember those moments that during apartheid divided these groups. Such divisions can be reconciled with determination and forgiveness. We argue that members of the BUSA and BCSA who continue to relive divided moments of the past should rethink their actions and work for true reconciliation with one another.

\section{Conclusion}

The Baptist Church, as it has been discussed in this article, has a long history which could be interpreted in varied ways, and particularly when either the BUSA or BCSA actively interpret their side of the story. The critical moment in time for the Baptist denomination in South Africa came when factions in the denomination were unable to aside their differences and merge into a singular organisation. It is this critical moment which is at the core of the article. There is some implication that understanding more contemporary relationships within the Church depends on revisiting the time period covered, which places this article much more within a contemporary framework in terms of trying to think about how to reconcile current factions which continue to harbour animosity, fracturing any attempt to build contemporary relationships. From experiences of working with Baptist members, examining the reconciliation documents between the BUSA and the BCSA, as well as listening to people at the local church and regional levels, it is clear that how people interpret the history of the Union and Convention seems to drive a major rift between these groups (Ntombana 2007:3). People are still arguing about who did what to whom; Black members of the BUSA and BCSA are still arguing about who betrayed whom. This article argues against justifying which action was right and which was wrong. Rather, this article is much more concerned with returning to those key moments when the BUSA and BCSA were divided, in order to stimulate the debate that, now more so than ever, these groups require faith to forgive, reconcile and move on from the past. The consequence for remaining fixated by the past events of apartheid is a rather bleak one. Whilst reconciliation often requires humility, and the willingness to suspend one's historical judgement, humility is perhaps the strongest weapon for bringing the BUSA and BCSA together.

\section{Acknowledgements Competing interests}

The authors declare that they have no financial or personal relationship(s) which may have inappropriately influenced them in writing this article.

\section{Authors' contributions}

As the primary author, L.N. (University of Fort Hare) conducted the research and most of the preliminary writing, whilst A.P. (University of Fort Hare) contributed in terms of writing as well and in the final refining and editing of the article. 


\section{References}

Belhar confession, 1982, viewed n.d., from http://www.warc.ch/pc/20th/02.html Bermejo-Barrera, J.C., 1993, 'Experiencing the past in praise of history', History and Theory 32, 14-21.

Bevir, M., 1994, 'The context of modernity', History and Theory 33, 28-40.

Braun, R., 1994, 'Holocaust and problems of historical representation', History and Theory 33, 172-197.

Brooks, A. \& Brickhill, J., 1980, Whirlwind before the storm: The origins and development of theuprising in Soweto and the rest of South Africa from June to December 1976, International Defence \& Aid Fund for Southern Africa, London.

Dray, W., 1980, Perspectives on history, Routledge \& Kegan Paul, London.

Hale, F., 2006, 'Baptist Union of Southern Africa and apartheid', Journal of Church and State 48, 753-777. http://dx.doi.org/10.1093/jcs/48.4.753

Hoffmeister, D. \& Gurney, J. (eds.), 1990, The Barkly West national awareness workshop, Baptist Convention of South Africa, Johannesburg.

Kairos Theologians, 1987, The Kairos document: The challenge to the Church Theological commentson political crisis in South Africa, rev. 2nd edn., Stokaville Publishers, Braamfontein.

Kretzschmar, L., 1996, 'The South African context', in L. Kretzschmar \& R. Richards (eds.), Reading the Bible in context: Reconstructing South Africa, 2nd Winter School of Theology, pp. 36-50, Baptist Convention of South Africa, Johannesburg.

Makhanya, G., 1990, 'History of the Baptist Convention of southern Africa', in D. Hoffmeister \& J. Gurney (eds.), The Barkley West awareness workshop, pp. 33-42, Baptist Convention of SouthAfrica, Johannesburg.

Martin, R. 1993, 'Objectivity and meaning in historical studies', History and Theory 32, 25-50. http://dx.doi.org/10.2307/2505328

Mccullagh, C.B., 2000, 'Bias in historical description, interpretation and interpretation', Historyand Theory 39, 49-56. http://dx.doi.org/10.1111/0018-2656.00112

Mhlophe, F.P., 1990, 'The effects of apartheid on Baptist Convention pastors in South Africa', in D. Hoffmeister \& J. Gurney (eds.), The Barkley West awareness workshop, pp. 53-58, Baptist Convention of South Africa, Johannesburg.

Mitchell, M., 1991, Paul and the rhetoric of reconciliation: An exegetical investigation of the languageand composition of 1 Corinthians, Westminster John Knox Press, Louisville, KY.
Ndlovu, S.M., 1998, The Soweto uprisings: Counter-memories of June 16, Ravan Press, Randburg.

Ntombana, L., 2007, 'An investigation into the reconciliation and unity process between the Baptist Convention and the Baptist Union of South Africa', unpublished MTheol dissertation, Department of Theology and Religion, University of Fort Hare.

Nurnberger, K. \& Tooke, J. (eds.), 1988, The cost of reconciliation in South Africa, Methodist Publishing House, Cape Town.

Prozesky, M., 1990, Christianity amidst apartheid: Selected perspectives on the Church in South Africa, Macmillan, Basingstoke.

Rae, T., 2004, 'Baptist history in South Africa', paper presented to the Baptist World Alliance Conference in Seoul, South Korea, 26-31 July, viewed n.d., from http:// www.bwa-baptistheritage.org/sl-raerec.htm

Richards, R. 1996, 'The South African context', in L. Kretszchmar \& P. Richards (eds.), Readingthe Bible in context, Reconstructing South Africa, 2nd Winter School of Theology, pp. 36-50, Baptist Convention of South Africa, Johannesburg.

Rusen, J., 2005, Making sense of history, History: Narration, interpretation, orientation, Berghahn Books, New York, NY.

Shafer, R.J., 1980, 'The nature of history', in R.J. Shafer (ed.), A guide to historical method, pp. 1-38, Dorsey Press, Homewood.

Sinclair, V., 1997, 'The sovereignty of God in reconciliation with Karl Barth as guide', Irish Biblical' Studies 18, 144-157.

Stanford, M., 1987, The nature of historical knowledge, Basil Blackwell, Cambridge, MA.

Thomas, R.J., 2005, 'Discerning Synoptic Gospel origins: An inductive approach', The Master Seminary Journal 16, 7-47.

Tunca, D., 2009, 'Redressing the narrative balance subjection and subjectivity in Chika Unigwe's On Black Sisters' Street', Afroeuropa 3, 1-18.

Tutu, D., 1997, 'Foreword', in H.R. Botman \& R.M. Peterson (eds.), To remember and to heal: Theological and psychological reflections on truth and reconciliation, pp. 7-8, Human \& Rosseau, Cape Town.

Williams, T.D., 2004, Vincum Amoris: A theology of the Holy Spirit, iUniverse, Inc., New York, NY. 